\title{
5 \\ Exploring Identities Through Poetic Inquiry: Heartful Journeys Into Tangled Places of Complicated Truths and Desires ${ }^{1}$
}

John J. Guiney Yallop, Kathleen Naylor, Shamimara Sharif, \& Nancy Taylor Acadia University

One of the challenges we face in higher education is knowing who we are as individuals and as communities. Poetic inquiry (Prendergast, Leggo, \& Sameshima, 2009) is a way into that knowing, a way of exploring our own identities and our relationships with each other. Poetic inquiry creates a space for evocative knowing. This research project, supported by the Acadia University Research Fund, included two graduate students as co-participants, one graduate student as co-investigator, and a principal investigator. Through writing, feedback, editing, and rewriting, we sought to create poetry that would show our identities as individuals and in relationships with our communities. We met for four three-hour sessions to write poetry, after reading the work of a poet/scholar. For our fifth session, we performed our poetry at a public reading that was advertised throughout the University community. Audience members were given a copy of our chapbook of poetry (Guiney Yallop, Naylor, Sharif, \& Taylor, 2009), which included participant-selected pieces from our own work completed during, or between, the sessions. ${ }^{2}$

\section{Opening}

$\int_{2009,}$ ohn: When I write a poem I'm doing research (Day \& Guiney Yallop, 2009; Guiney Yallop, 2009, 2008, 2005) and when I'm doing research it usually results in a poem. The poems written and shared during this study are evocative. They bring us into experiences. They reveal identities - sometimes painfully, sometimes joyfully, always with an openness to human experience.

\footnotetext{
${ }^{1}$ The subtitle for this paper comes from Carl Leggo (e-mail communication) in response to our chapbook (Guiney Yallop, Naylor, Sharif, \& Taylor, 2009).

${ }^{2}$ Note: A chapbook of poetry is a non-periodical collection of poetry in print that does not have the required number of pages for a book.
} 
We chose different sites throughout our university and its surrounding communities in which to write because, in addition to exploring our identities and our relationships with our communities, we also wanted to explore the effect of place on our writing. Our writing was therapeutic; we make no apologies for research that is healing. We celebrate research that gives something to participants.

Sections from my doctoral dissertation (Guiney Yallop, 2008) constituted our reading for the first session where we discussed poetic inquiry and wrote in response to the question Who am I?

Who are we? We are man and woman. We are minority - visible and invisible; we are majority. We are young and we are old. We are parent, partner, daughter, son, uncle, aunt, sister, brother, and friend. We are educator and student. We are participant and researcher. We are individual and we are community.

Cornelia Hoogland's (2005) award-winning chapbook, Second Marriage, was read in preparation for our second session where we talked and wrote about our theme of "relationships." Our identities are connected to our relationships - to who we are as individuals within and without communities.

Our third session was built around a discussion of, and response to, Carl Leggo's (2006) most recent collection of poetry, Come-By-Chance. For session three, our theme was "longing."

For our fourth session, we were delighted to be joined by Lorri Neilsen Glenn, poet and scholar, and Poet Laureate for Halifax Regional Municipality 2005-2009. In preparation for that session, we read Lorri's recent collection of poetry (Neilsen Glenn, 2007), Combustion. We chose "possibilities" as the theme of our writing for session four.

Kathleen: When we began, I was tentative about what might 'count' as graduate-level research. Thankfully, the richness of each person's writing and of our conversations soon drew me in, and I let go of preconceived notions. The writing and sharing of the poems offered a new way for me to understand the complexities of my personal and professional development as a counsellor. I now understand poetic inquiry as a way of learning that is necessarily both reflective and experiential.

Shamim: When Nancy first suggested I be a participant in a research project on poetic inquiry, my insides laughed - Me? Poetry? She must be joking! I expressed my doubts to John, too. However, against my own judgement, I accompanied Nancy, more out of my affection and respect for her. I don't exactly know when the initial hesitation and reluctance changed to fascination for the discovery of the new self. That self, awakened in this journey with John, Kathleen, and Nancy, may never sleep again - ever.

The fact that I have a poem in me is a discovery, like a new world.

It's a very strange feeling, you know like something you knew existed but did not know what it was.

I suppose everyone has a poem in them waiting to come out.

Nancy: It was the word "identity" that grabbed me initially. I was struggling with my identity as a mature student in a university that mostly offers undergraduate programs. I was trying to connect with other mature women who were feeling invisible on campus. I was struck by one woman who referred to herself as a loser because she didn't complete some formal education when she was younger. I felt like a winner doing graduate studies. I like diversity: sexualities, ethnicities, age, class, gender, abilities. When I experience diversity, I can be myself. I love poetry and research. I am a risk taker. All these elements attracted me to the project.

\section{The Poetry}

John: My writing, my research, is about identities 
- my own identities. I am in an ongoing process of discovering, struggling with, understanding, and embracing my identities. This poem was written some weeks after I was diagnosed with prostate cancer, a diagnosis I received half-way into this research project. I am indebted to Colin Bernhardt (in conversation) for the visualization exercise which led to this poem.

\section{Untitled [For Now]}

I go out

to other universes

riding

on the rhythms of space

and a voice.

I see everyone

every molecule of creation.

I take all back

gently

inside me

pulling myself

gently

back into myself.

Sounds echo

from the chambers

of my past-

ancestors who remembered me

before I was born.

I breathe in the center

of who I am.

Healing.

Caring.

Loving.

Embracing my world

and its inhibitions.

Shamim: This past year I had to explore difficult questions about my identity. Many of my assumptions about who I am, my very being, were shattered. I walked a painful path with John, Nancy, and Kathleen, and, through it all, somewhere in the background, was family - 60 individuals who love me. My poem "Shifting” is all about moving. Shifting was an important aspect of my life in India and I think has added diversity to my identity. This poetic inquiry brought me face to face with the differences and similarities in thoughts, cultures, and languages of Canada and India.

\section{Shifting}

Twenty years of married life

umar armaan zeeshan and me

shifted twelve houses

Twelve times my world

turned into a few

scattered cardboard boxes

Twelve times I opened a new door

Twelve times one week felt like one hour

Twelve times I told myself

"Not to worry ... Everything is going to be OK"

Twelve times I he you and them

fused

Nancy: "Solipsism" wrote itself, beginning with the first thought that came to my mind. What emerged reflects my challenge in finding a voice for my passions - a gentle, practical voice that others can take in, even though it often describes my anguish. Now I sense a tension between knowledge and wisdom, self and other, order and chaos, creativity and dogma. The three women I name are leaders in movements to which I ascribe; each has contributed to my understanding of global despair and all have been role models in my academic journey. Naming them here somehow supports my emerging identity. Yes, and my age plays a part in both my struggles to be heard and to be silent. I am discovering how elders in my own life complete the human ecology. 


\section{Solipsism}

I can't think of anything smart to write

I want to write something profound

I want to use big words

like ubiquity

solipsism or quantum

With quantum this and quantum that I could sound brilliant

with original thoughts

slipping effortlessly from my brain out of my mouth

in soft seductive tones

words received with oohs and aahs yeah ... that makes sense

isn't she smart, so original

like Danah Zohar, Margaret Wheatley, Joanna Macy

I want to make sense be systematic pragmatic grounded

yet still reaching up so high

that my finger tips disappear briefly

teasing down indigo petals

falling softly

to land in chaos around my silver crown

Kathleen: "Possibilities" emerged in another writing space during the course of the research project; I was surrounded by teenage writers, and soaking up their wonderful vibes. As a graduate student in a counselling program, I'd been having lots of conversations about how to work with the notion of potential in people's lives. This poem teeters on the edge of being about me and being about me as a counsellor, working with the possibilities of others. 


\title{
Possibilities
}

\author{
possibilities \\ must be tricked sometimes \\ into \\ stepping out into the light.
}

they prefer to cower.

if left to their own devices, they will lounge around inside

bumping into one another in the dark.

I find

if I make concessions, make an offer

enticing enough

I can tempt possibility into showing itself.

so, I offer humility.

trade hard work for a moment of peace.

a possibility responds in kind,

inches forward out of safety,

dripping limitations from its coatsleeves

and leaving fear behind in muddied footprints.

\section{Closing}

Shamim: There is no end to this journey. Its vastness is like the horizon. The distance I have covered from where I started fascinates me, and the limitless possibilities are exciting.

Kathleen: Now that the research is finished, and I've completed my graduate program, I'm extremely thankful for the opportunities this research project created. I was craving an outlet that allowed me to explore the effects of the experience of graduate studies on me as a changing person, and the effects of that change on my relationships as well. This project gave me permission not only to explore those aspects with the group, but to share them publicly with my own community web of family, friends, and academic faculty. The performance and publication drew the threads of my graduate student identity into a tighter weave.
Nancy: I'm reminded of T. S. Eliot's words from "Little Gidding": "The end is where we start from." I have finished my work at the university and I have returned to my old life. Seeds of poetry continue to germinate within me from the research. I wonder how my identity will shift from my experience as a student and whether I can nurture the changes in spite of the pressures of my rural community to remain the same. Can I integrate a new identity as a poet into my old life? Can I risk exposing tender parts of myself to others who assume to know me well? Shall I risk appearing an old fool?

John: Leading a research project about identities when my own world was unsettled to the core with the discovery of a new identity - a person with cancer - reminded me of how research can be personally meaningful. Poetic inquiry is a form of research that can help us renew our understanding of our own lives, and make new connections with the lives of others. I am grateful to Kathleen, Nancy, and Shamim for their thoughtful engagement in this journey. 


\section{References}

Day, L. \& Guiney Yallop, J.J. (2009). Learning, teaching, and researching through poetry: A shared journey. Creative Approaches to Research, 2(2), 46-57.

Guiney Yallop, J.J. (2009). Being a poetic researcher: Holding the tension of artist in the academy and academic in the world. The International Journal of the Arts in Society, 4.

Guiney Yallop, J.J. (2008). OUT of place: A poetic journey through the emotional landscape of a gay person's identities within/without communities. (Unpublished doctoral thesis). University of Western Ontario, London, ON.

Guiney Yallop, J.J. (2005). Exploring an emotional landscape: Becoming a researcher by reawakening the poet. Brock Education, 14(2), 132144.

Guiney Yallop, J.J, Naylor, K., Sharif, S., \& Taylor, N. (2009). Exploring identities through poetic inquiry. Wolfville, NS: Authors.

Hoogland, C. (2005). Second marriage. London, ON: Canadian Poetry Association.

Leggo, C. (2006). Come-by-chance: A collection of poems. St. John's, NL: Breakwater Books.

Neilsen Glenn, L. (2007). Combustion. London, ON: Brick Books.

Prendergast, M., Leggo, C., \& Sameshima, P. (2009). Poetic inquiry: Vibrant voices in the social sciences. Rotterdam, The Netherlands: SensePublishers.

\section{Biographies}

John J. Guiney Yallop is a parent, a partner, and a poet. He is also an Assistant Professor in the School of Education at Acadia University where he teaches literacy and writes poetry.

Kathleen Naylor now holds a Master of Education in Counselling from Acadia University. She lives on the south shore of Nova Scotia where she practices the crafts of counselling, community-building, and creative exploration.

Nancy Taylor has a B.A. (Women's Studies and Sociology) from the University of Victoria and recently completed a Master of Education in Counselling at Acadia University. She works as a counsellor, clinical supervisor, and facilitator in the public and private sectors in rural BC.

Shamimara Sharif is a woman with a husband, kids, family, friends, and a job (student support teacher). She holds a Master of Education from Acadia University. 